DOI: $10.30519 /$ ahtr. 970292

Advances in Hospitality and Tourism Research (AHTR)

\title{
BIGGER AND COMPLEX IS NOT ALWAYS BETTER. THE CREATION OF COMPOSITE SUSTAINABLE TOURISM INDICATOR TO COMPARE DESTINATION DEVELOPMENT
}

\author{
Matúš MARCIŠ 1 \\ Faculty of Economics, Matej Bel University in Banská Bystrica, Slovakia \\ ORCID: 0000-0002-4860-3105 \\ Tomáš GAJDOŠÍK \\ Faculty of Economics, Matej Bel University in Banská Bystrica, Slovakia \\ ORCID: 0000-0002-2879-8005
}

\begin{abstract}
Destination managers need indicators for monitoring, comparing and decision-making purposes about sustainable tourism development. There have been several initiatives to set the sustainable tourism indicators, however, the indicators are either too complex, data collection is difficult, or the analysis requires expert statistical knowledge. Therefore, this article aims to propose a user-friendly method that allows destination managers and decision makers to process tourism data and integrate them into one composite indicator. To help destination managers in their work, this paper reviews the most used methods to create composite indicators, and with the help of the Delphi method among experienced tourism leaders, it proposes a tool that allows
\end{abstract}

\section{Article History}

Received 12 July 2021

Revised 6 December 2021

Accepted 24 December 2021

Published online 2 February 2022

\section{Keywords}

composite indicator sustainable tourism

Delphi method

min max method

\section{INTRODUCTION}

Sustainable development requires the integration of its principles into all tourism activities. As Ko (2005) notes, if sustainable development is one of

\footnotetext{
${ }^{1}$ Address correspondence to Matúš Marciš (Ph.D.), Faculty of Economics, Matej Bel University in
} Banská Bystrica, Slovakia. E-mail: matus.marcis@umb.sk 
the major current tourism objectives, then the sector should monitor its performance and impacts. To ensure that the sustainable development of tourism is realistic and not-only a theoretical concept, it is necessary to apply appropriate tools to measure its impacts (Falatooni et al., 2016; Liu, 2003; Miller \& Twining-Ward, 2005). However, universally accepted guidelines for measuring sustainable tourism development have not yet been determined, but practices from different areas of research are combined in attempts to measure it (Kožić \& Mikulić, 2014). Therefore, there is no generally accepted proposal to measure sustainable tourism development (Alfaro Navarro et al., 2020; Torres-Delgado \& Saarinen, 2014), and the most common frameworks includes the sets of indicators. Tanguay and Rajaonson (2013) concluded that, in developing sustainable tourism indicators, there have been many failures, either because the suggested frameworks did not meet the desired requirements, or for the reason that they were not based on relevant sources. Methodological difficulties may also reduce the applicability of indicators (Kristjánsdóttir et al., 2018). Therefore, not only the theory (Torres-Delgado \& Saarinen, 2014) but also the practice call for the easy-to-use method for measuring sustainable tourism development.

This paper provides a review of the existing literature in the sustainable tourism monitoring and the use of composite indicators in sustainable tourism research. Furthermore, it discusses the practical application of composite indicators in tourism destinations. Based on the literature review and with the help of the Delphi method among tourism experts, this paper proposes a user-friendly method that allows destination managers and decision makers to process various tourism data and integrate them into one composite indicator. The study seeks to find answers to two research questions;

RQ1: What are the limits of the methods used for constructing the composite sustainable indicators for tourism?

RQ2: Which method is suitable for the simple and practical adoption of the composite sustainable indicator for tourism?

The study continues as follows. The first section summarizes the literature on sustainable tourism indicators and presents methods used to create aggregate sustainable tourism indicators. The second section points out methodology, explains application of Delphi method and the selection of suitable statistical method. The application of the proposed method is presented in the third section. The conclusions and practical and theoretical implications are summarized in the fourth section. 


\section{LITERATURE REVIEW}

Without indicators, the term "sustainable" becomes little more than a meaningless phrase (Butler, 1999; Wheeller, 1993). Liu (2003) notes that the measurement of sustainable tourism development is crucial, since there is an urgent need to develop policies and methods that are not only theoretically sound but practically viable as well. Sustainable indicators can be defined as "a set of measures that provide the necessary information to better grasp the relationships and the impact of tourism on the cultural and natural resources in which tourism takes place and on which it is strongly dependent" (World Tourism Organization, 1996, p. 4). Since the introduction of the concept of sustainability in tourism, there have been efforts to monitor the performance of nations and businesses in new frameworks, models, and indicators (Niyazieva \& Zhechev, 2020). Indicators of sustainable tourism development follow the concept of sustainability, its tools and they include a set of measures that help to understand the relationship between tourism development and resources on which it depends (World Tourism Organization, 2004). Indicators are used for multidimensional evaluating of destination development (Blancas et al., 2015). Several researchers and stakeholders have proposed different frameworks and/or sets of indicators for monitoring sustainable tourism. Several researchers and stakeholders have proposed different frameworks and/or sets of indicators. Indicators can be grouped into two main categories: simple indicators and composite-aggregated indicators (indices) (Pulido-Fernández \& Sánchez-Rivero, 2009). Simple indicators are based on real data and provide information that is based on minimal data processing (Torres-Delgado \& Saarinen, 2014), while indices (complex or composite indicators) combine and weight numerous simple indicators (PulidoFernández \& Sánchez-Rivero, 2009). The advantage of a composite indicator is that it describes different data in an aggregated form that is more understandable to the user (Saltelli, 2007). Mayer (2008) simply adds that a composite indicator is a combination of several indicators that can provide an overall description of a system. Composite indicator can be used to analyse multidimensional systems, as a tourism destination, that cannot be measured by single indicators. Additionally, the combination of numerous data into a composite indicator can help tourism stakeholders to understand the overall performance of the destination and to compare the performance with others (Castellani \& Sala, 2010). There can also be an indicator system that contains a set of multiple indicators (Torres-Delgado \& Saarinen, 2014). 
As Ceron and Dubois (2003) conclude, setting the right indicators requires a high level of contingency, while implementing them requires a high level of pragmatism. An indicator system is not useful when, for example, the user realizes that it is difficult to gather data, or it is time consuming, or an indicator is completely meaningless for the user's destination (Johnsen et al., 2008). The indicator system should be straightforward enough to be understood and applied also by the nonprofessional (White et al., 2006). Despite the fact that sustainable tourism monitoring has become more popular among academia, non-governmental organizations, and also among tourism professionals, its impact on real policies and their efficiency has been minimal (Pulido-Fernández \& Sánchez-Rivero, 2009). Appropriate sets of tourism measures recommended by researchers are usually too complicated to be adopted by tourism professionals and policymakers (Tanguay \& Rajaonson, 2013). Indicators need to be methodologically and scientifically settled, while at the same time, easily applied and their results readily disseminated (TorresDelgado \& Saarinen, 2014). Applicable and reliable tourism measures should be developed with practical implementation at national, regional and local level in mind (Wanner et al., 2020).

So far, several indicator systems have been proposed, either as a set of simple indicators (Agyeiwaah et al., 2017; Asmelash \& Kumar, 2019; Choi \& Sirakaya, 2006; Tanguay \& Rajaonson, 2013) or with a proposal of a composite indicator (Blancas et al., 2015; Torres-Delgado \& López Palomeque, 2018). Some indicator systems have major practical limitations, while others are scientifically valid but too complicated to be functional (Torres-Delgado \& Palomeque, 2014) and present a theoretical description of the framework without its real application (Blancas et al., 2015). Not all research results can provide appropriate sustainable tourism frameworks applicable to other destinations (Fernández-Tabales et al., 2017). PulidoFernández et al. (2015) agree that a common criticism of sustainable tourism development is that both academia and policymakers have taken the concept on board with too much enthusiasm but a lack of solutions. The authors add that researchers have proposed a quantity of theories, however, only a few practical schemes, whereas policymakers have used the concept for their own purposes. Bigger is not always better, especially within sustainable tourism development (Agyeiwaah et al., 2017). Regardless of the number of indicators proposed, their methodological processing and interpretation is needed. In recent years, a growing number of models for the composite indicator have been seen that aim to propose a complex and simple interpretation of the concept of sustainable tourism (Torres-Delgado 
\& López Palomeque, 2018). However, their application by destination managers and decision-makers is questionable and under-researched. Therefore, this article aims to propose an easy-to-use comprehensive method that allows destination managers and decision-makers to process available tourism data and integrate them into one composite indicator.

Various techniques have been used to create a composite indicator (OECD, 2008). These techniques depend mostly on the user's skills (researcher or policymaker). So, the user must select which technique to apply considering methodology, such as choosing indicators, their classification, application of normalization method, indicators weighting and aggregation (Nardo et al., 2005). Various studies have shown that (e.g. Blancas et al., 2011; Castellani \& Sala, 2010; OECD, 2008), there are several techniques to propose a composite sustainable tourism indicator and the study findings indicate that there is no ideal method (Pérez et al., 2013). Furthermore, the statistical methods used to create the composite indicator (data normalisation or aggregation) also provide a variety of modifications. All this leads to the fact that each method has a different result.

Table 1. Method used for constructing composite sustainable indicators for tourism

\begin{tabular}{|c|c|c|c|}
\hline $\begin{array}{l}\text { Author(s) and year of } \\
\text { publication }\end{array}$ & $\begin{array}{c}\text { No } \\
\text { indicators }\end{array}$ & $\begin{array}{c}\text { Method used for constructing composite } \\
\text { sustainable tourism indicator }\end{array}$ & Application \\
\hline $\begin{array}{l}\text { Pulido-Fernández \& Sánchez- } \\
\text { Rivero (2009) }\end{array}$ & 14 & $\begin{array}{c}\text { Composite indicator as a weighted sum of } \\
\text { aggregate indices applying a confirmatory } \\
\text { factor analysis }\end{array}$ & Spain \\
\hline Castellani \& Sala (2010) & 20 & $\begin{array}{c}\text { Sustainable performance index as a sum of } \\
\text { the values of } 20 \text { indicators }\end{array}$ & Italy (Lombardy) \\
\hline Blancas et al. (2011) & 85 & $\begin{array}{l}\text { Principal component analysis and distance } \\
\text { to reference point }\end{array}$ & Spain (Andalusia) \\
\hline Lozano-Oyola et al. (2012) & 85 & Net goal programming synthetic indicator & Spain (Andalusia) \\
\hline Pérez et al. (2013) & 39 & $\begin{array}{c}\text { Two stage aggregation using principal } \\
\text { component analysis and data envelope } \\
\text { analysis }\end{array}$ & Cuba \\
\hline Kožić \& Mikulić (2014) & 30 & $\begin{array}{l}\text { Composite indicator using data } \\
\text { standardization method }\end{array}$ & Croatia \\
\hline Blancas et al. (2015) & 89 & Net goal programming composite indicator & $\begin{array}{l}\text { EU countries, } \\
\text { Norway, } \\
\text { Switzerland }\end{array}$ \\
\hline Blancas et al. (2016) & 85 & $\begin{array}{l}\text { Vectorial dynamic composite indicator based } \\
\text { on the goal programming technique }\end{array}$ & $\begin{array}{l}\text { EU countries, } \\
\text { Norway }\end{array}$ \\
\hline Fernández-Tabales et al. (2017) & 43 & $\begin{array}{l}\text { Multi-attribute decision analysis and } \\
\text { analytic hierarchy process }\end{array}$ & Spain (Andalusia) \\
\hline Ziaabadi et al. (2017) & 87 & $\begin{array}{c}\text { Principal component analysis, linear } \\
\text { programming }\end{array}$ & $\begin{array}{l}\text { Iran (Kerman } \\
\text { Province) }\end{array}$ \\
\hline $\begin{array}{l}\text { Torres-Delgado \& López } \\
\text { Palomeque (2018) }\end{array}$ & 12 & $\begin{array}{l}\text { Composite indicator using data } \\
\text { standardization method }\end{array}$ & Spain (Catalonia) \\
\hline Alfaro Navarro et al. (2020) & 27 & $\begin{array}{c}\text { Principal component analysis, linear } \\
\text { aggregation method }\end{array}$ & EU' NUTS II \\
\hline Blancas et al. (2018) & 65 & $\begin{array}{l}\text { Vectorial composite indicator using cluster } \\
\text { analysis }\end{array}$ & Spain (Andalusia) \\
\hline
\end{tabular}


So far, within the sustainable tourism research, only a few studies have addressed the construction of composite sustainable tourism indicators (Kristjánsdóttir et al., 2018; Torres-Delgado \& López Palomeque, 2018). The process usually involves steps in which subjective decisions have to be made, such as the choice of indicators, indicator weighting and aggregation (Pérez et al., 2013). Various studies have proposed different methods for constructing composite indicator for the tourism sector (Table 1). However, what is often overlooked is the end-user's ability to use and process these indicators. Destination managers, policy-makers and other stakeholders may lack the ability to work with sophisticated and complex computing relationships. Although the manager can understand the result, he/ she is not able to repeat the procedure or apply it in his conditions whether due to lack of understanding or time or both.

This can lead to ignorance and reluctance to apply similar methods (Agyeiwaah et al., 2017). There is, therefore, the question that, if apart from academics, someone else has applied the proposed indicators. The results of the method used for constructing a composite sustainable tourism indicator (applying principal component analysis or linear programming) can be easily interpretable but, if someone wants to adopt them, they need to understand at least complex computing relationships. However, if the preconditions are not met, applying a principal component analysis or factor analysis based weights to create composite indicator can be inaccurate and also irrational (Falatooni et al., 2016). Therefore, there is a need for an easy-to-use comprehensive method that both theory and praxis can rely on.

\section{METHODOLOGY}

\section{Relevant input indicators selection}

In order to use relevant indicators for the method, the list of most-used sustainable tourism indicators both in theory and practise have been evaluated by experts using the Delphi method. Miller and Twining-Ward (2005) defined the Delphi method as a unique technique that involves stakeholder or expert group brainstorming to fill the gaps in the knowledge. In tourism research, the Delphi technique has been widely used. For example, Choi and Sirakaya (2006) used a modified Delphi method to select sustainability indicators. The design of the survey and the suitability of the technique were pretested by the sample of 15 experts from Slovakia (Gúčik \& Marciš, 2018). 
First, based on the reviewed studies (e. g. Blancas et al., 2011; Castellani \& Sala, 2010; European Commission, 2016), a list of 30 most used indicators for constructing composite sustainable tourism indicator was created. Subsequently, for the Delphi panel, tourism experts were selected from the public sector, academic institutions and destination management organizations (DMOs). The main criterion for the Delphi panel was expert experience in tourism development in selected Central and Eastern European (CEE) countries (Slovakia, Czech Republic, Croatia and Slovenia) (Table 2).

Table 2. The panel members' institutions

\begin{tabular}{|c|c|c|}
\hline $\begin{array}{l}\text { Destination management } \\
\text { organizations }\end{array}$ & $\begin{array}{c}\text { Public institutions and } \\
\text { agencies }\end{array}$ & Academic institutions \\
\hline Slovak DMO association & $\begin{array}{l}\text { Ministry of transport and } \\
\text { construction of Slovakia, } \\
\text { Tourism section }\end{array}$ & $\begin{array}{c}\text { Faculty of Economics and } \\
\text { Administration Masaryk University, } \\
\text { Czech Republic }\end{array}$ \\
\hline DMO Banská Štiavnica, Slovakia & $\begin{array}{l}\text { Ministry of environment of } \\
\text { Slovakia }\end{array}$ & $\begin{array}{c}\text { Faculty of European Studies and } \\
\text { Regional Development Slovak } \\
\text { University of Agriculture in Nitra, } \\
\text { Slovakia }\end{array}$ \\
\hline DMO Central Slovakia & $\begin{array}{l}\text { Ministry of transport of Czech } \\
\text { Republic, Tourism section }\end{array}$ & $\begin{array}{l}\text { TURISTICA University of Primorska } \\
\text { - Faculty of Tourism Studies } \\
\text { Portorož, Slovenia }\end{array}$ \\
\hline DMO Visit Bratislava, Slovakia & $\begin{array}{c}\text { Goodplace Travel Lab, } \\
\text { Slovenia }\end{array}$ & $\begin{array}{l}\text { Faculty of Economics Matej Bel } \\
\text { University, Slovakia }\end{array}$ \\
\hline DMO High Tatras, Slovakia & Mitomed+, Croatia & \\
\hline
\end{tabular}

After agreeing to participate in a panel, a group of 25 experts was identified representing tourism leaders with expertise and experience from CEE countries. The panel members were then asked to complete an online survey that consisted of three sections. In the panel first section, the panellists were asked to assess the importance of sustainable tourism indicators and their applicability for destination managers and policy makers, as well as the character of the indicator. In the second section, the panel members were asked to review methods used to create a composite indicator based on the OECD (2008) and to evaluate its applicability in the practice of destination management. The last section was for additional experts' comments and suggestions. The experts were contacted in three rounds, the response rate achieved $76 \%$.

Based on their opinions and consensus, a set of 23 indicators of sustainable tourism development was created specifying the data sources needed for their collection (Table 3). Indicators were classified into three, most recognised, categories of sustainable tourism (Lozano-Oyola et al., 2012; Blancas et al., 2015), namely economic, social and environmental. The ideal number of indicators to apply in sustainable tourism research is 
unclear. If we use only some indicators, important gaps can be overlooked. On the other hand, applying too many indicators can become difficult and unmanageable. However, according to the World Tourism Organization (2004), it is optimal to use 12 to 24 indicators relevant to the priority issue. Furthermore, there is still no agreement among academics on which indicators are suitable to evaluate the sustainable development of tourism (Önder et al., 2017). Most of the selected indicators of sustainable tourism development cannot be expressed by the available statistical data. To collect data, the panellist proposed to use survey templates from the European Tourism Indicator System (ETIS) (European Commission, 2016).

Table 3. Sustainable tourism indicators

\begin{tabular}{|c|c|c|}
\hline Ref. & Sustainable tourism indicators & Data Source \\
\hline E1 & Nights spent at tourist accommodation establishments (per year) & OS \\
\hline E2 & Average number of bed nights of tourists & OS, QT \\
\hline E3 & Average accommodation occupancy rate for the year (\%) & OS, QT \\
\hline E4 & Tourist' daily spending (euros) & QT \\
\hline E5 & Tourism contribution to employment (\% of total employment) & QP \\
\hline E6 & Percentage of jobs in tourism that are seasonal (\%) & QP \\
\hline E7 & $\begin{array}{l}\text { Percentage of locally produced goods and services sourced by the destination's tourism service } \\
\text { providers (\%) }\end{array}$ & QP \\
\hline E8 & Residents' engagement in providing tourism services (\%) & QR \\
\hline S1 & Number of tourists per 1000 residents & OS \\
\hline S2 & Percentage of tourists satisfied with tourism development (\%) & QT \\
\hline S3 & Percentage of residents satisfied with tourism development (\%) & QR \\
\hline S4 & Percentage of tourists who prefer regional consumption (\%) & QT \\
\hline S5 & Accessibility of tourism service providers for people with disabilities (\%) & QP \\
\hline S6 & $\begin{array}{l}\text { Percentage of tourism service providers that have committed to support local community and } \\
\text { culture }(\%)\end{array}$ & QP \\
\hline S7 & The number of local DMO members (\% of total number of tourism service providers) & OS, QP \\
\hline S8 & Residents' engagement in the development of tourism in the destination (\%) & QR \\
\hline $\mathrm{Z1}$ & Percentage of tourists using different modes of transport to arrive at the destination (\%) & QT, QP \\
\hline $\mathrm{Z} 2$ & Percentage of tourists using soft mobility transport services to get around the destination (\%) & QT, QP \\
\hline $\mathrm{Z3}$ & Percentage of tourism service providers that have committed to reduce waste production (\%) & QP \\
\hline $\mathrm{Z4}$ & Percentage of tourism service providers that have committed to reduce water consumption (\%) & QP \\
\hline Z5 & $\begin{array}{l}\text { Percentage of tourism service providers that have committed to reduce energy consumption } \\
(\%)\end{array}$ & QP \\
\hline Z6 & Percentage of tourism service providers involved in nature protection activities (\%) & QP \\
\hline $\mathrm{Z7}$ & Tourism carrying capacity (coefficient) & OS, QR, QT \\
\hline
\end{tabular}

\section{The selection of suitable statistical method}

To create an easy-to-use composite indicator, there is a need for simple, but on the other hand comprehensive method to reduce the information from selected indicators that both theory and praxis agree on. Multidimensional statistical methods, such as CFA, PCA, or cluster analysis, are used mainly for academic purposes and are hardly applicable by destination managers 
in practice. The experts in Delphi method agreed that the suitable easy-touse method can be the variation of the Min-Max method. Originally, the Min Max method allows normalization of different indicators and is used in time-dependent studies (OECD, 2008), where the minimum and maximum values are transformed into normalised indicators with values between 0 (laggard) and 1 (leader).

The proposed variation of the Min-Max method also incorporates a scoring system and allows to compare different variables (e.g. percentages, persons, overnights, tourists' spending) and imply them into one indicator - score for the destination (or for each dimension). This method also enables indicators weighting if they are of different importance (e.g. based on the results of Delphi study). The indicators can be compared with their measured variables and aggregated into composite indicators. Furthermore, the proposed variation of Min-Max method allows to set apart whether the value of the indicator should be maximized (1) or minimized (2) based on its development in other comparable destinations.

$$
\begin{aligned}
& \text { (1) } B_{i j}=\frac{X_{i j}}{X_{\max i}} \times 100 \\
& \text { (2) } B_{i j}=\frac{X_{\min i}}{X_{i j}} \times 100
\end{aligned}
$$

where $B_{i j}$ is the number of points or score for indicator $(i)$ destination $(j)$, $X_{i j}$ - value of the $i$-indicator for $j$-destination (rescaled value), $X_{\max i}$ - the maximum value of $i$-indicator and $X_{\min i}$ - the lowest value of the $i$ indicator. The best-evaluated (leader) destination gets maximum (e. g. 100) points, i.e. measured value that is from the sample the best. The indicators can be integrated into one composite indicator (I), which can be expressed as weighted arithmetic mean of all indicators:

$$
\text { (3) } I=\frac{1}{n} \sum_{i=1}^{n} B_{i j} \times w_{i j}
$$

where $i$ is $1,2 \ldots n$ number of used indicators, $j$ - number of destination in the sample, $w_{\mathrm{ij}}$ - indicator weight. The lowest score identifies the least (laggard) sustainable destination and highest the best destination (leader) within the sample.

Indicators can be weighted by numerous procedures such as datacentric or opinion-centric approaches (Delphi method or expert panel surveys) (Mikulić et al., 2015). This brings about further variations in the process of creating a composite indicator. In sustainable tourism research, the Delphi method has been used for indicator weighting in several studies 
(e.g., Ocampo et al., 2018; Tsaur et al., 2006). In the proposed method, weights were calculated based on the mean importance assigned to the indicator according to the Delphi results. The weights were determined as the ratio of the assigned mean (importance) and the maximum rating that the panelists could assign to the indicator (Appendix A).

The Min-Max normalization is one of the most common ways to normalize data. Similarly to our variation, it has been used in regional science to compare regional development (Tej, 2008; Výrostová, 2010). Regional development as well as tourism is a complex and complicated process that is influenced by many factors and conditions. The method provides a relatively objective and broad view of the possibilities of development compared to other spatial units.

\section{RESULTS}

In order to test the applicability of the proposed method in the practice, eight tourism destinations in the Central European country - Slovakia were selected. The research sample consists of urban (Bratislava, Košice, Central Slovakia), rural (Slovak paradise, Žitný ostrov), mountain destinations (High Tatras, Liptov), and a spa destination (Pieštany). These are the most competitive destinations in Slovakia (Kvasnová et al., 2019). The sample characteristics are shown in Table 4.

Table 4. Basic characteristics of the sample

\begin{tabular}{lcccc}
\hline Destination & Overnight stays & Beds & Population & Area in sq. km \\
\hline Bratislava & 2719733 & 16185 & 424428 & 367 \\
Košice & 367725 & 5772 & 239171 & 242.8 \\
Liptov & 387357 & 14019 & 72396 & 477.7 \\
Piešt’any & 663806 & 4768 & 32431 & 44.2 \\
Slovak paradise & 157892 & 2390 & 84116 & 553 \\
Central Slovakia & 518692 & 5660 & 135274 & 421.5 \\
High Tatras & 2084632 & 11665 & 59038 & 485.9 \\
Žitný ostrov & 94186 & 4163 & 52144 & 208.5 \\
\hline
\end{tabular}

Source: Statistical Office of the Slovak Republic, 2019

The official statistics and primary surveys were used to collect the input data. Questionnaires for tourists, residents, and tourism services providers were designed based on the ETIS templates (European Commission, 2016) in the Slovak language. With the help of destination managers in each destination, 639 tourists, 326 tourism service providers, and 680 residents provided information during the summer and winter seasons of 2018. 
The results of the proposed variation of the Mix-Max method and the scores for the partial indices (sustainable tourism dimensions) as well as the composite sustainable tourism indicator (I), are shown in Table 5.

Table 5. Comparison of sustainable tourism development in Slovak destinations

\begin{tabular}{lcccc}
\hline Destination & $I$ & \multicolumn{3}{c}{ Sustainable Tourism Dimensions } \\
\cline { 3 - 5 } & & Economic & Social & Environmental \\
\hline Pieštany & 64 & 59 & 65 & 71 \\
High Tatras & 60 & 62 & 59 & 52 \\
Košice & 57 & 49 & 64 & 58 \\
Slovak paradise & 57 & 42 & 64 & 66 \\
Bratislava & 52 & 58 & 43 & 54 \\
Central Slovakia & 51 & 47 & 52 & 53 \\
Liptov & 50 & 44 & 58 & 50 \\
Žitný ostrov & 49 & 42 & 47 & 61 \\
\hline
\end{tabular}

The advantage of this method is the ability to compare the results among destinations. In this study, destination Pieštany shows the highest tendency to sustainable development of tourism (leader), whereas Žitný ostrov presents the lowest (laggard). The destination Pieštany obtained the best results for indicators such as (E2) average length of stay, (S5) percentage of tourism enterprises and attractions accessible for people with disabilities, and (Z3) percentage of tourism enterprises that reduce waste production. These results are in line with the spa character of Pieštany. Overall, Pieštany obtained the best values, which we used as a basis for comparison with other case studies, in five indicators. The lowest number of points was assigned to the destination Žitný ostrov, e. g. for (E3) the average occupancy rate in commercial accommodation, (S3) residents' satisfaction with the tourism development, and the proportion of tourism enterprises and attractions that are involved in the activities of the local DMO (Figure 1).

Considering the results obtained, it is useful to note that the composite indicator has no lower or higher limits; instead, the results can specify the gaps between destinations. Therefore, regarding the sustainable or unsustainable development of tourism in destination, we can only discuss it in comparable terms. Moreover, the differences among indicators or dimensions can be evaluated by dispersion of values used (e.g. variance or standard deviation). In this study, the Slovak paradise (National park) obtained lower points for economic indicators (e.g. for average length of stays, average occupancy rate, and high percentage of seasonal employees) but on the contrary, higher points for environmental indicators (tourism enterprises that reduce waste production and are actively involved in nature protection). 


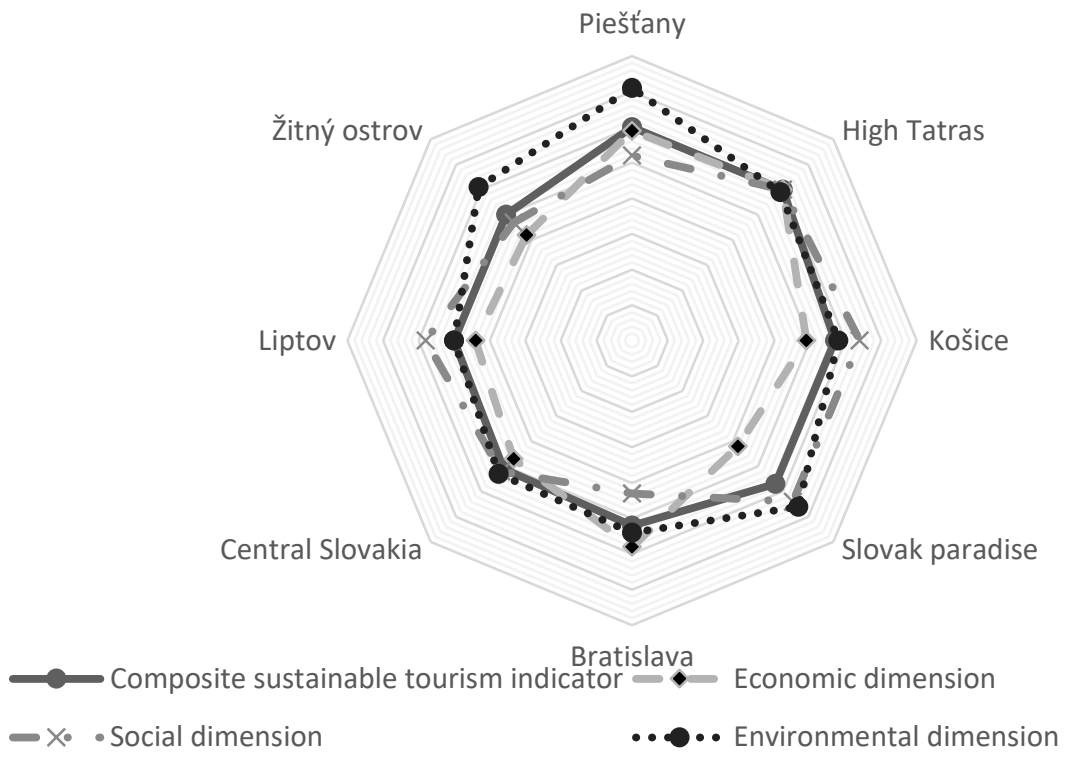

Figure 1. Comparison of sustainable tourism development in analysed destinations

The method can be enriched by modelling the "best practice" destination, where the best indicator values are assigned to a fictional object - a model of the ideal destination. To express differences among destinations, the Euclidean distances can be calculated. The further the destination is from the model of ideal destination, the worse ranked their indicators values are. This measurement is able to highlight the differences between destinations and identify a model that presents the best (ideal) examples of sustainable tourism development (Figure 2).

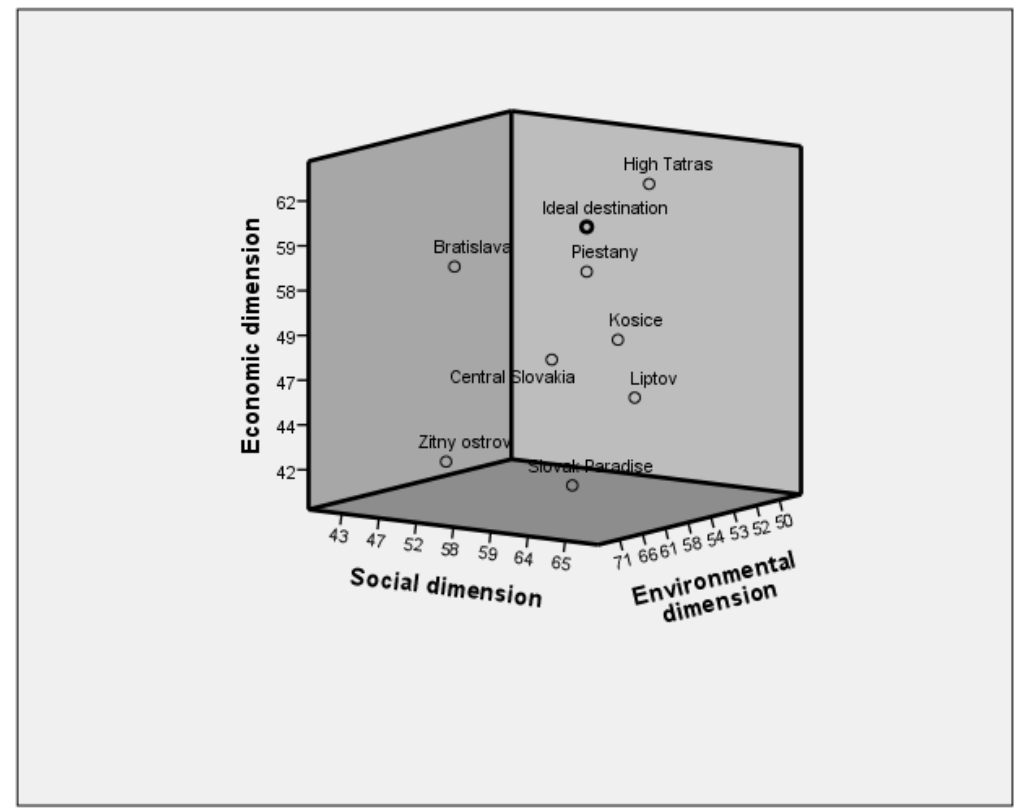

Figure 2. Distance of destinations from the ideal model 


\section{CONCLUSION}

Tourism is a sector known for weak statistical data, while issues related to sustainable development create an additional amount of uncertainty (Ceron \& Dubois, 2003). By applying an appropriate method, destination managers and decision-makers can identify positive or negative impacts of tourism in the destination. There are numerous studies that have proposed methods for constructing and use of composite indicators for the tourism sector. Each had to face the questions that arise due to the lack of agreement regarding the ideal technique (Torres-Delgado \& López Palomeque, 2018). However, destination managers' and policy-makers' ability to use such methodology is often overlooked. These methods are generally too complex to be operational which can lead to end-user ignorance and reluctance.

On the example of tourism development in eight destinations in Slovakia, this article incorporates a simple variation of the Min-Max method. Instead of developing a too complex data processing methodology, the authors focused on a simple and practical-oriented method that can be adopted easily. Adopting smaller, yet practicable measures may represent a formidable action towards sustainability (Agyeiwaah et al., 2017). In other words, policymakers can apply the proposed methodology to begin the process of monitoring and measuring destination development.

Theoretical implications of the study include the review of current approaches to sustainable tourism monitoring using composite indicator. The literature review reveals that the creation of an appropriate sustainable tourism framework calls for a combination of a scientific approach and a decision-maker approach (Falatooni et al., 2016). The current study supports this theoretical discussion and proposes a method that is based on the views of those to whom these methods are intended. Prior studies have identified several indicators for sustainable tourism development. Although these frameworks are scientifically appropriate, they are often difficult to be applied due to the lack of information or human resources (Önder et al., 2017). Indicators for monitoring sustainable tourism development should be developed in discussion with all stakeholders (Mutana \& Mukwada, 2018). With the help of the Delphi method and experts from various tourism fields and destination managers, the proposed method allows measuring different tourism-related variables with an easily understandable and more user-friendly approach. Another theoretical contribution is the review of the most widely used method for constructing composite sustainable tourism indicators. 
In addition, the paper has several practical implications for destination managers and policy-makers. The challenge, to propose a practical framework that can be used in practice and at the same time is scientifically relevant to direct destinations toward sustainable tourism development (Torres-Delgado \& Palomeque, 2014), was fulfilled. The aggregation of various tourism data into a single indicator can help destination managers and decision-makers to recognize the impacts of tourism development and to compare the performance of their destination with different regions. The study's interest in the composite indicators results from their ability to aggregate several factors and conditions, provide a broader, integrated overview, and attract decision-makers' interest. Another practical implication of the proposed method is that it can simply analyse numerous data, which means the destination managers and policymakers find it easier to understand. It also enables indicator weighting if they are of different importance and sets apart whether the value of the indicator should be maximized or minimized.

The limitations of the study lie in the possible risk of subjectivity, which may despite applied Delphi method and theoretical background have affected the indicator selection, assignment of weights and values. Another limiting factor is also the focus only on the selected experts from the CEE countries and the character of the static indicators. Therefore, the method should be tested in the praxis of several destinations to prove its usefulness. In the near future, new tools, in terms of data used (e.g. big data), their collection (smart sensors, web scrapping), exchange (dynamic technological platforms with APIs), and analysis (sentiment analysis) can lead to much more understandable, real-time and user-friendly construction of composite sustainable tourism indicator, which can lead to smart destination development.

\section{ACKNOWLEDGMENT}

The research was supported by the research project VEGA 1/0237/20 Tourism 4.0: Smart and sustainable tourism development in a competitive environment.

\section{REFERENCES}

Agyeiwaah, E., McKercher, B., \& Suntikul, W. (2017). Identifying core indicators of sustainable tourism: A path forward? Tourism Management Perspectives, 24, 26-33. https://doi.org/10.1016/j.tmp.2017.07.005

Alfaro Navarro, J. L., Andrés Martínez, M. E., \& Mondéjar Jiménez, J. A. (2020). An approach to measuring sustainable tourism at the local level in Europe. Current Issues in Tourism, 23(4), 423-437. https://doi.org/10.1080/13683500.2019.1579174 
Asmelash, A. G., \& Kumar, S. (2019). Assessing progress of tourism sustainability: Developing and validating sustainability indicators. Tourism Management, 71, 6783. https://doi.org/10.1016/j.tourman.2018.09.020

Blancas, F. J., Lozano-Oyola, M., \& González, M. (2015). A European Sustainable Tourism Labels proposal using a composite indicator. Environmental Impact Assessment Review, 54, 39-54. https://doi.org/10.1016/j.eiar.2015.05.001

Blancas, F. J., Lozano-Oyola, M., González, M., \& Caballero, R. (2016). Sustainable tourism composite indicators: a dynamic evaluation to manage changes in sustainability. Journal of Sustainable Tourism, 24(10), 1403-1424. https://doi.org/10.1080/09669582.2015.1122014

Blancas, F. J., Lozano-Oyola, M., González, M., \& Caballero, R. (2018). A dynamic sustainable tourism evaluation using multiple benchmarks. Journal of Cleaner Production, 174, 1190-1203. https://doi.org/10.1016/j.jclepro.2017.10.295

Blancas, F. J., Lozano-Oyola, M., González, M., Guerrero, F. M., \& Caballero, R. (2011). How to use sustainability indicators for tourism planning: The case of rural tourism in Andalusia (Spain). Science of the Total Environment, 412-413, 28-45. https://doi.org/10.1016/j.scitotenv.2011.09.066

Butler, R. W. (1999). Sustainable tourism: A state-of-the-art review. Tourism Geographies, 1(1), 7-25. https://doi.org/10.1080/14616689908721291

Castellani, V., \& Sala, S. (2010). Sustainable performance index for tourism policy development. Tourism Management, 31(6), 871-880. https://doi.org/10.1016/j.tourman.2009.10.001

Ceron, J. P., \& Dubois, G. (2003). Tourism and sustainable development indicators: The gap between theoretical demands and practical achievements. Current Issues in Tourism, 6(1), 54-72. https://doi.org/10.1080/136835003086667944

Choi, H. S. C., \& Sirakaya, E. (2006). Sustainability indicators for managing community tourism. Tourism Management, 27(6), 1274-1289. https://doi.org/10.1016/j.tourman.2005.05.018

European Commission. (2016). European Tourism Indicators System for sustainable destination management. ETIS Toolkit for Sustainable Destination Management. Retrieved August 20 2018, from https://ec.europa.eu/growth/sectors/tourism/offer/sustainable/indicators_sk

Falatooni, E., Selen, W., \& Kerr, D. (2016). A new framework for selecting composite indicators to assess sustainability of a destination. Athens Journal of Tourism, 3(1), 7-24. https://doi.org/10.30958/ajt.3-1-1

Fernández-Tabales, A., Foronda-Robles, C., Galindo-Pérez-de-Azpillaga, L., \& GarcíaLópez, A. (2017). Developing a system of territorial governance indicators for tourism destinations. Journal of Sustainable Tourism, 25(9), 1275-1305. https://doi.org/10.1080/09669582.2016.1260136

Gúčik, M., \& Marciš, M. (2018). Sustainable development of tourism: transition from global to local dimension. In T. Kliestik (Eds.), Proceedings of the 18th International Scientific Conference Globalization and Its Socio-Economic Consequences (pp. 2525-2531). University of Zilina, Slovakia. Retrieved January 27, 2022, from https://globalizacia.com/past-proceedings

Johnsen, J., Bieger, T., \& Scherer, R. (2008). Indicator-based strategies for sustainable tourism development. Mountain Research and Development, 28(2), 116-121. https://doi.org/10.1659/mrd.0973 
Ko, T. G. (2005). Development of a tourism sustainability assessment procedure: A conceptual approach. Tourism Management, 26(3), 431-445. https://doi.org/10.1016/j.tourman.2003.12.003

Kožić, I., \& Mikulić, J. (2014). Research note: Measuring tourism sustainability: An empirical comparison of different weighting procedures used in modelling composite indicators. Tourism Economics, 20(2), 429-437. https://doi.org/10.5367/te.2013.0283

Kristjánsdóttir, K. R., Ólafsdóttir, R., \& Ragnarsdóttir, K. V. (2018). Reviewing integrated sustainability indicators for tourism. Journal of Sustainable Tourism, 26(4), 583-599. https://doi.org/10.1080/09669582.2017.1364741

Kvasnová, D., Gajdošík, T., \& Maráková, V. (2019). Are partnerships enhancing tourism destination competitiveness? Acta Universitatis Agriculturae et Silviculturae Mendelianae Brunensis, 67(3), 811-821. https://doi.org/10.11118/actaun201967030811

Liu, Z. (2003). Sustainable tourism development: A critique. Journal of Sustainable Tourism, 11(6), 459-475. https://doi.org/10.1080/09669580308667216

Lozano-Oyola, M., Blancas, F. J., González, M., \& Caballero, R. (2012). Sustainable tourism indicators as planning tools in cultural destinations. Ecological Indicators, 18, 659675. https://doi.org/10.1016/j.ecolind.2012.01.014

Mayer, A. L. (2008). Strengths and weaknesses of common sustainability indices for multidimensional systems. Environment International, 34(2), 277-291. https://doi.org/10.1016/j.envint.2007.09.004

Mikulić, J., Kožić, I., \& Krešić, D. (2015). Weighting indicators of tourism sustainability: A critical note. Ecological Indicators, 48, 312-314. https://doi.org/10.1016/j.ecolind.2014.08.026

Miller, G., \& Twining-Ward, L. (2005). Monitoring for a sustainable tourism transition: The challenge of developing and using indicators. Wallingford: CABI Publishing.

Mutana, S., \& Mukwada, G. (2018). Mountain-route tourism and sustainability. A discourse analysis of literature and possible future research. Journal of Outdoor Recreation and Tourism, 24, 59-65. https://doi.org/10.1016/j.jort.2018.08.003

Nardo, M., Saisana, M., Saltelli, A., \& Tarantola, A. (2005). Tools for Composite Indicators Building. EUR 21682 EN. 2005. JRC31473. Retrieved October 20, 2019 from https://publications.jrc.ec.europa.eu/repository/bitstream/JRC31473/EUR\%202168 $2 \% 20 \mathrm{EN}$.pdf

Niyazieva, S., \& Zhechev, V. (2020). Could happiness be an assessment tool in sustainable tourism management? Advances in Hospitality and Tourism Research, 8(2), 338-370. https://doi.org/10.30519/ahtr.749680

OECD. (2008). Handbook on Constructing Composite Indicators: Methodology and UserGuide. OECD. Paris.

Ocampo, L., Ebisa, J. A., Ombre, J., \& Escoto, M. G. (2018). Sustainable ecotourism indicators with fuzzy Delphi method - A Philippine perspective. Ecological Indicators, 93, 874-888. https://doi.org/10.1016/j.ecolind.2018.05.060

Önder, I., Wöber, K., \& Zekan, B. (2017). Towards a sustainable urban tourism development in Europe. Tourism Economics, 23(2), 243-259. https://doi.org/10.1177/1354816616656247

Pérez, V., Guerrero, F., González, M., Pérez, F., \& Caballero, R. (2013). Composite indicator for the assessment of sustainability: The case of Cuban nature-based tourism destinations. Ecological Indicators, 29, 316-324. https://doi.org/10.1016/j.ecolind.2012.12.027 
Pulido-Fernández, J. I., Andrades-Caldito, L., \& Sánchez-Rivero, M. (2015). Is sustainable tourism an obstacle to the economic performance of the tourism industry? Evidence from an international empirical study. Journal of Sustainable Tourism, 23(1), 47-64. https://doi.org/10.1080/09669582.2014.909447

Pulido-Fernández, J. I., \& Sánchez-Rivero, M. (2009). Measuring tourism sustainability: proposal for a composite index. Tourism Economics, 15(2), 277-296. https://doi.org/https://doi.org/10.5367/000000009788254377

Saltelli, A. (2007). Composite indicators between analysis and advocacy. Social Indicators Research, 81(1), 65-77. https://doi.org/10.1007/s11205-006-0024-9

Statistical Office of the Slovak Republic (2019). Sector statistics: Tourism. Retrieved September 15, 2019, from https://slovak.statistics.sk/

Tanguay, G. A., \& Rajaonson, J. (2013). Selection and use of sustainable tourism indicators in the evaluation of projects and policies. Transfert, 1, 116-128.

Tej, J. (2008). Point method for the assessment of regional development - possibilities and practical application. Folia Geographica 12, 268-277.

Torres-Delgado, A., \& López Palomeque, F. (2018). The ISOST index: A tool for studying sustainable tourism. Journal of Destination Marketing and Management, 8, 281-289. https://doi.org/10.1016/j.jdmm.2017.05.005

Torres-Delgado, A., \& Palomeque, F. L. (2014). Measuring sustainable tourism at the municipal level. Annals of Tourism Research, 49, 122-137. https://doi.org/10.1016/j.annals.2014.09.003

Torres-Delgado, A., \& Saarinen, J. (2014). Using indicators to assess sustainable tourism development: a review. Tourism Geographies, 16(1), 31-47. https://doi.org/10.1080/14616688.2013.867530

Tsaur, S. H., Lin, Y. C., \& Lin, J. H. (2006). Evaluating ecotourism sustainability from the integrated perspective of resource, community and tourism. Tourism Managemnt, 27(4), 640-653. https://doi.org/10.1016/j.tourman.2005.02.006

Výrostová, E. (2010). Regionálna ekonomika a rozvoj. Bratislava: Wolters Kluwer (Iura Edition).

Wanner, A., Seier, G., \& Pröbstl-Haider, U. (2020). Policies related to sustainable tourism An assessment and comparison of European policies, frameworks and plans. Journal of Outdoor Recreation and Tourism, 29, 100275. https://doi.org/10.1016/j.jort.2019.100275

Wheeller, B. (1993). Sustaining the ego. Journal of Sustainable Tourism, 1(2), 121-129. https://doi.org/10.1080/09669589309450710

White, V., McCrum, G., Blackstock, K. L., \& Scott, A. (2006). Indicators of Sustainability \& Sustainable Tourism: Some Example Sets. The Macaulay Institute.

World Tourism Organization. (1996). What Tourism Managers need to know: A practical guide to the development and use of Indicators of Sustainable Tourism. https://doi.org/doi/abs/10.18111/9789284401505

World Tourism Organization. (2004). Indicators of sustainable development for tourism destinations: a guidebook. World Tourism Organization.

Ziaabadi, M., Malakootian, M., Zare Mehrjerdi, M. R., Jalaee, S. A., \& Mehrabi Boshrabadi, H. (2017). How to use composite indicator and linear programming model for determine sustainable tourism. Journal of Environmental Health Science and Engineering, 15(1). https://doi.org/10.1186/s40201-017-0271-5 
Appendix A. Descriptive statistics and weights of sustainable tourism indicators

\begin{tabular}{|c|c|c|c|c|c|}
\hline Sustainable tourism indicators & Mean & SD & Max & Min & $W$ \\
\hline $\begin{array}{l}\text { Nights spent at tourist accommodation } \\
\text { establishments (per year) }\end{array}$ & 868675 & 978485 & 2719733 & 94186 & 0.800 \\
\hline Average number of bed nights of tourists & 2.4 & 1.2 & 5.0 & 1.3 & 0.724 \\
\hline $\begin{array}{l}\text { Average accommodation occupancy rate for the } \\
\text { year }(\%)\end{array}$ & 29.9 & 11.4 & 44.0 & 14.4 & 0.830 \\
\hline Tourist' daily spending (euros) & 62.8 & 14.7 & 80.2 & 42.3 & 0.830 \\
\hline $\begin{array}{l}\text { Tourism contribution to employment (\% of total } \\
\text { employment) }\end{array}$ & 20.4 & 8.0 & 31.0 & 11.0 & 0.830 \\
\hline Percentage of jobs in tourism that are seasonal (\%) & 13.5 & 6.5 & 22.3 & 2.5 & 0.770 \\
\hline $\begin{array}{l}\text { Percentage of locally produced goods and services } \\
\text { sourced by the destination's tourism service } \\
\text { providers }(\%)\end{array}$ & 63.6 & 11.43 & 75.0 & 48.0 & 0.862 \\
\hline $\begin{array}{l}\text { Residents' engagement in providing tourism } \\
\text { services }(\%)\end{array}$ & 31.9 & 6.16 & 40.0 & 18.0 & 0.846 \\
\hline Number of tourists per 1000 residents & 9574 & 12107 & 35310 & 1537 & 0.816 \\
\hline $\begin{array}{l}\text { Percentage of tourists satisfied with tourism } \\
\text { development }(\%)\end{array}$ & 80.3 & 7.5 & 90.0 & 69.0 & 0.800 \\
\hline $\begin{array}{l}\text { Percentage of residents satisfied with tourism } \\
\text { development }(\%)\end{array}$ & 84.0 & 7.8 & 93.0 & 71.0 & 0.908 \\
\hline $\begin{array}{l}\text { Percentage of tourists who prefer regional } \\
\text { consumption }(\%)\end{array}$ & 61.3 & 10.4 & 75.0 & 50.1 & 0.784 \\
\hline $\begin{array}{l}\text { Accessibility of tourism service providers for } \\
\text { people with disabilities (\%) }\end{array}$ & 55.4 & 14.4 & 70.7 & 33.3 & 0.724 \\
\hline $\begin{array}{l}\text { Percentage of tourism service providers that have } \\
\text { committed to support local community and } \\
\text { culture }(\%)\end{array}$ & 59.9 & 16.4 & 80.5 & 32.3 & 0.784 \\
\hline $\begin{array}{l}\text { The number of local DMO members (\% of total } \\
\text { number of tourism service providers) }\end{array}$ & 42.1 & 11.0 & 56.0 & 21.1 & 0.754 \\
\hline $\begin{array}{l}\text { Residents' engagement in the development of } \\
\text { tourism in the destination (\%) }\end{array}$ & 30.5 & 8.7 & 48.3 & 17.8 & 0.900 \\
\hline $\begin{array}{l}\text { Percentage of tourists using different modes of } \\
\text { transport to arrive at the destination }(\%)\end{array}$ & 58.3 & 16.1 & 80.6 & 32.9 & 0.770 \\
\hline $\begin{array}{l}\text { Percentage of tourists using soft mobility } \\
\text { transport services to get around the destination } \\
(\%)\end{array}$ & 51.8 & 15.5 & 74.6 & 33.3 & 0.830 \\
\hline $\begin{array}{l}\text { Percentage of tourism service providers that have } \\
\text { committed to reduce waste production (\%) }\end{array}$ & 72.6 & 18.6 & 90.2 & 45.7 & 0.924 \\
\hline $\begin{array}{l}\text { Percentage of tourism service providers that have } \\
\text { committed to reduce water consumption (\%) }\end{array}$ & 52.0 & 10.1 & 65.9 & 35.6 & 0.892 \\
\hline $\begin{array}{l}\text { Percentage of tourism service providers that have } \\
\text { committed to reduce energy consumption (\%) }\end{array}$ & 66.0 & 8.9 & 79.2 & 51.1 & 0.892 \\
\hline $\begin{array}{l}\text { Percentage of tourism service providers involved } \\
\text { in nature protection activities (\%) }\end{array}$ & 55.1 & 15.6 & 83.3 & 37.1 & 0.908 \\
\hline Tourism carrying capacity (coefficient) & 2.8 & 0.7 & 4.3 & 2.3 & 0.830 \\
\hline
\end{tabular}

Mean: mean value of the indicator for the sample, SD: Standard deviation, Max: maximal value, Min: minimal value, $W$ : indicator weight based on the results of Delphi method as a ratio between mean importance and maximal rating, e.g. 4.5 to 5. 